\title{
MODERNIST NARRATIVE TECHNIQUES IN THE SCREEN ADAPTATION OF THE NOVEL MINUET FOR GUITAR
}

\author{
LIDIJA REZONIČNIK
}

\begin{abstract}
Modernist narrative techniques in the screen adaptation of the novel „Minuet for Guitar". This contribution focuses on the novel Minuet for Guitar, by the Slovenian author Vitomil Zupan, and its film adaptation, entitled Farewell until the Next War, by the Serbian director Živojin Pavlović. Firstly the article deals with the novel from the perspective of modernist narrative devices, and secondly it focuses on an analysis of its cinematic adaptation. Based on the anthropological and morphological method of film analysis it establishes that Živojin Pavlović used modernist narrative devices in the film. Furthermore, it studies how and through which cinematic forms of expressions and methods both the stream of consciousness and memories are shown, as well as how essayistic style, fragmentariness, and associative style are expressed in audio-visual representation.
\end{abstract}

STRESZCZENIE. Modernistyczne techniki narracji w adaptacji filmowej powieści „Menuet za kitaro”. Artykuł poświęcony jest powieści Menuet za kitaro, napisanej przez słoweńskiego pisarza Vitomila Zupana, oraz jej adaptacji filmowej pod tytułem Nasvidenje v naslednji vojni, którą nakręcił serbski reżyser Živojin Pavlović. Pierwsza część artykułu skupia się na samej powieści, która jest przedstawiona pod kątem postrzegania modernistycznych technik narracji, a druga część poświęcona jest jej adaptacji filmowej. Badania antropologicznomorfologiczne dzieła filmowego pozwoliły ustalić, że Živojin Pavlović stosuje w filmie modernistyczne techniki narracji. Dalsza analiza pokazuje, w jaki sposób, oraz jakimi filmowymi środkami wyrazu jest przedstawiony w adaptacji filmowej strumień świadomości, pamięć, a także jak za pomocą audiowizualnych środków wyrażone są styl eseistyczny, fragmentaryczność oraz styl asocjatywny.

Author: Lidija Rezoničnik, Department of Slavistics, Faculty of Arts, University of Ljubljana, Aškerčeva 2, SI-1000 Ljubljana, Slovenia, lidija.rezonicnik@gmail.com

Keywords: Vitomil Zupan, Minuet for Guitar, Živojin Pavlović, Farewell until the Next War, modernist novel, film adaptation, stream of consciousness, interior monologue

Balcanica Posnaniensia. Acta et studia, XXIV, Poznań 2017, Wydawnictwo Instytutu Historii UAM, pp. 143154, ISBN 978-83-65663-50-4, ISSN 0239-4278. English text with summaries in English and Polish.

doi.org/10.14746/bp.2017.24.9

\section{INTRODUCTION}

The film genre began as an advancement of the photographic reproduction of reality ("...moving pictures", e.g. the first silent films from the Brothers Lumière at the end of the 19th century, which portray everyday scenes - the arrival of a train at the station, people departing a factory - without editing or cutting scenes, and without a nar- 
rative structure), which led to the early conviction that film should especially portray phenomena from the real, material world. Through history the medium of film, also or perhaps especially because of technological advances, developed a diverse range of expressive media, both at the level of picture (mise en scène ${ }^{1}$ : dominance, lighting, distance between camera and scene, angle, color, lens/filter/film, contrast, density, composition, form, framing, depth, character layout, staging, distance between characters) and sound (voices, music, silence), as well as at the level of editing and acting. These means of expression make it possible for the film to portray a non-linear and fragmented narrative, or subjective experience.

The current paper discusses the modernist novel Minuet for Guitar $^{2}$, by Slovenian author Vitomil Zupan, and its film adaptation, Farewell until the Next War, from Serbian director Živojin Pavlović, taking as its thesis that Pavlović's film employs modernist narrative techniques. The starting point for analyzing the film adaptation is grounded in the supposition that the basis for the film's screenplay is the novel's narrative, but the ultimate product is an independent work, wherefore I shall avoid analytical methods employing the concept of the film adaptation's fidelity or lack thereof to the literary original, which is often discussed in adaptation theory and analysis ${ }^{3}$, though more modern theories consider such a concept as insufficient ${ }^{4}$. The analysis of the film in question follows the anthropological or morphological method ${ }^{5}$, which respects the multifacetedness of the film (audiovisual qualities, joint authorship, etc.), and accordingly studies it through analysis of individual elements and the relationships between them. The first phase (horizontal analysis) focuses on individual components of the film's narrative - space and time, content and form, sound and picture, the character's appearance and internal world. In doing so the analyst is interested in how space, time, content, form, sound, picture, and appearance are conveyed through the medium of film: in mise en scène, movement, editing, music or sound, and acting. In the second phase (vertical analysis) there follows an interpretation, which describes the film's means of expression and their role in its narrative. Here it is important that explanations do not have the character of one-sided and final conclusions, as even with the use of scientific methodological apparatus it is impossible that said explanations would be completely objective.

Before undertaking an analysis of the film Farewell until the Next War this paper will present the novel Minuet for Guitar as its literary basis, particularly from the perspective of modernist narrative devices.

${ }^{1}$ Cf., e.g., a chapter about the analysis of the mise en scène in: L. Giannetti, Razumeti film, Ljubljana 2008, p. 49-101.

${ }^{2}$ V. Zupan, Menuet za kitaro, Ljubljana 1984.

${ }^{3}$ E.g. George Bluestone, Alfred Estermann, Geoffrey Wagner, Dudley Andrew, Linda Constanzo Cahir etc. Cf., e.g., a review of the methods used to analyze the film adaptations: M. Rudolf, Ko beseda podobo najde. Slovenska literatura in film v teoriji in praksi (1984-2012), Ljubljana 2013, p. 73-143.

${ }^{4}$ E. g. Briane McFarlane, Novel to Film (1996); Linda Hutcheon, A Theory of Adaptation (2006); Thomas Leitch, Film Adaptation \& Its Discontents (2007) etc.

${ }^{5}$ Cf. S. Kuśmierczyk, Wyprawa bohatera w polskim filmie fabularnym, Warsaw 2014, p. 11-34. 


\section{THE NOVEL MINUET FOR GUITAR}

Vitomil Zupan, writer, poet, playwright, and essayist, was born in 1914 in Ljubljana, dying in 1987 in the very same city. In terms of content and form his world followed the literary currents of modern European literature, and thus went against the predominant trends in Slovenian literature, as a result of which they gained broad and final acceptance only in the 1970s. These days the most well-known works in Zupan's canon are prose writings, for example Potovanje na konec pomladi (Journey to the end of spring), Klement (Klement), Zasledovalec samega sebe (The self-pursuer), Mrtva mlaka (Dead water), and Igra s hudičevim repom (Playing with the Devil's Tail). Minuet for Guitar, along with his novels Komedija človeškega tkiva (A human tissue comedy) and Levitan (Leviathan), form their own "war" trilogy".

Zupan's novel Minuet for Guitar, which was first published in 1975, joins within a two-part space-time perspective the narrative of soldier Jakob Bergant (Berk) about his experience as a Partisan, as well as the memories of the older Jakob Bergant ${ }^{7}$, who recalls them during a vacation in a Spanish tourist town in 1973. In the introductory explanation the reader learns that the book was written on the basis of Berk's diary, or notes, which the so-called transcriber fleshed out and turned into a story. The narrative framework and the interlacing of the factual (parallels between the novel's events and Vitomil Zupan's life) and the fictive place the novel in the genre of works with autobiographical features, and, in addition to this, literary studies and critics describe the novel, in the light of genre syncretism, as a book of growth, and as a war ${ }^{8}$ and a picaresque novel ${ }^{9}$; they also recognize in the novel, besides the realistic, elements of existentialism, vitalism, and modernism. The first-person and personal narrator strings together select events from Berk's Partisan past on the basis of temporal and causal logic, and he intertwines his realistic narrative with a number of cognitive tangents. Aljoša Harlamov ${ }^{10}$ finds the novel to consist of realistic narrative processes, weaved together with modernist ones, wherefore he classifies it as a modernist historical novel.

\section{MODERNIST NARRATIVE TECHNIQUES IN MINUET FOR GUITAR}

Modernist literature interrupts realistic discourse, thereby losing its "narrativeness" in the traditional sense (linear narration, cause/effect relationships, rising and falling action around the climax, tendency toward objectiveness, etc.) and opening itself

\footnotetext{
${ }^{6}$ A. Berger, Na poti skozi čas in za seboj. In: Menuet za kitaro, Ljubljana 1984, p. 543-552.

${ }^{7}$ To make it easier to distinguish between the two levels of space and time I will continue to use the name Berk to refer to the protagonist youth and the Partisan period, and the name Bergant for the Spanish chronotope.

${ }^{8}$ N. Barbarič, Uvodna razlaga. In: Menuet za kitaro, Ljubljana 1999, p. 13-37.

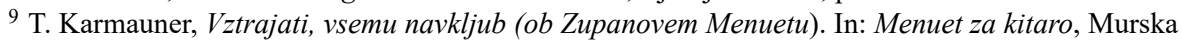
Sobota 1980, p. 477.

${ }^{10}$ A. Harlamov, Slovenski modernistični roman, Ljubljana 2016, p. 121.
} 
up to subjective poetics ${ }^{11}$. The modernist subject is unstable, decentralized (a lack of focus or centrality, metaphysical nihilism), and desubstantialized (is not a cohesive unit) $^{12}$. Harlamov ${ }^{13}$ joins both of them under the concept of the desubjectivization of the subject, which in prose is effected through modernist narrative methods, especially with the stream of consciousness and internal monologue, which include fragmentedness and associative links. The stream of consciousness narration implies a stream of events in unconnected, unconscious, intercrossing reminiscences of those who are part of the narrative ${ }^{14}$, and is therefore often fragmentary. Literary studies treat the stream of consciousness as a broader concept, in which the internal monologue is included as a structural and stylistic tool, marking the direct (with none of the narrator's interference) representation of an individual's consciousness (first-person narrative), their thoughts, feelings, memories, associations, etc. ${ }^{15}$. Jola Škulj ${ }^{16}$ further claims that, despite certain differences, both terms, the stream of consciousness and internal monologue, are often used synonymously. As this paper focuses on the literary, especially on the cinematic portrayal of consciousness, a precise distinction between the stream of consciousness and internal monologue is not important, and I will therefore use both terms interchangeably, and I will especially consider the broader concept of stream of consciousness. The disorientation of the modernist subject and the unreliability of reality are therefore reflected in a fragmented narrative, in associative links, which introduce digression into the narrative, or in long-winded writing longer descriptions, discursive/philosophical parts that, like an essay, slow down and deepen the narrative. Essayation, essayism, or discursiveness is introducing discursive elements into the narrative flow, thereby foregoing the principle of epic integration and the continuity of events, so that the story devolves until it falls apart ${ }^{17}$. This kind of narrative is no longer linear and oriented toward events, but is characterized by a typical circulation around the central object or around the key topics ${ }^{18}$.

The internal monologue in Minuet for Guitar is the main narrative technique through which we get to know Berk's/Bergant's consciousness, or the form by which

11 A. Eysteinsson, The concept of modernism, Ithaca and London 1992, p. 27-28.

12 J. Kos, Konec modernizma, ,Sodobnost”, 1988, no 3-7, p. 393.

13 A. Harlamov, Slovenski modernistični roman, Ljubljana 2016, p. 57-59.

14 J. Škulj, Modernizem in njegove poteze $v$ lirski, narativni in dramski formi, „Primerjalna književnost", 1998, vol. 21, no 2, p. 65.

${ }^{15}$ Alojzija Zupan Sosič emphasizes, in addition to internal monologue, the category of experienced or free dependent speech, which unlike internal monologue is written in the third person, and is thus characteristically double vision and the link between the internal monologue and narration, or the exchange between the narrator and literary subject. A. Zupan Sosič, Govor v sodobnem slovenskem romanu, „Slavistična revija”, 2015, vol. 63, no 2, p. 188.

16 J. Škulj, Modernizem in njegove poteze v lirski, narativni in dramski formi, „Primerjalna knjiŽevnost", 1998, vol. 21, no 2, p. 65.

${ }^{17}$ A. Zupan Sosič, Pimlico in Neznosna lahkost bivanja kot maturitetna romana, „Jezik in slovstvo”, 2006, vol. 51, no 6, p. 27.

18 Ibidem, p. 28. 
their direct experience is conveyed ${ }^{19}$. Berk is an individualist, obsessed with ontological, existential, and other questions, spurred by historical events and his being torn between reason, emotion, and his instinctual needs. Among the Partisans, besides Anton, he does not have an interlocutor of his caliber, and thus the majority of the speculation and debate occurs inside his head. Meanwhile the Spanish chronotope's considerations usually unfold through the dialog between Bergant and the former German soldier Bitter. But even Bitter is not on Bergant's level of consciousness, and their conversations are therefore most often just a starting point, which causes Bergant to reminisce, and that memory is conveyed as stream of consciousness. The stream of consciousness or internal monologue becomes most intense during moments of extreme exertion, for example during a hajka, or anti-Partisan military action, when Berk goes into a state of hallucination, and the border between the real and imaginary, and among the numerous minutiae of reality there sneaks a fantasy, and with it the fantastic, and the various temporal levels and the levels of feeling and perceiving are blurred and intertwined ${ }^{20}$. The cognitive breakdown is visible on the linguistic level, too: the narrative becomes ungrammatical, unpunctuated, and non-existent words and syllables are used:

Emotions that come or tarry - remnants of words and ideas floated up from the memory and sank again, merging transfused among images and sensations of what was and what had been yes now ben nota that's your quota - sketches descriptions oil paintings museums curtains knife trying to meet cannot approaching nearer running into the background colors woodcuts gnarled trees caricature novel picture war engravings chronicles of campaign films all quiet on the western front pen drawings plans of war rainfall frescoes colored wagons photographs toy swords shields lances jevelins helmets Ilium ponies printed page hamlet tree tents knife fight man with helmet perched naked in tree and it was all settled white cloth trimmed with lace ribbon coat-of-arms cannon ${ }^{21}$.

The novel's triggers of associative stream of memory are primarily Bitter, Anton, and the Minuet for Guitar, a melody that is present in both the Spanish and Partisan chronotopes ${ }^{22}$. Meeting with Bitter causes cognitive meditation in Bergant, in which from all angles and perspectives he always returns again to the topic of war and to the past. In distinction to Bergant, who is focused on rehashing memories, Berk is an active character, experiencing the war directly, and the reader gets to know him, as he acts, thinks, and reacts, on the sensual, emotional, and intellectual level ${ }^{23}$. Regardless of their temporal and spatial presence and their roles in the specific historical period, both characters work through similar topics, around which the narrative circles in the form of essays or cognitive or analytical intermezzos: on the sense of war, the relationship between war and peace, the infinitesimal (un)importance of an individual in the universe, the role of the individual in the system, the unpredictability of life, relative-

\footnotetext{
${ }^{19}$ M. Dolgan, Vitomil Zupan, Menuet za kitaro, „Sodobnost”, 1976, vol. 24, no 2, p. 172.

${ }^{20}$ A. Berger, Na poti skozi čas in za seboj. In: Menuet za kitaro, Ljubljana 1984, p. 557.

${ }^{21}$ V. Zupan, Minuet for Guitar, Champaign/Dublin/London 2011, p. 50.

${ }^{22}$ N. Barbarič, Uvodna razlaga. In: Menuet za kitaro, Ljubljana 1999, p. 17-18.

${ }^{23}$ Ibidem, p. 30.
} 
ness, purpose, etc. Numerous cognitive digressions in essayistic style do not impede the narrative, but rather deepen and broaden it, and form, as Alojzija Zupan-Sosič ${ }^{24}$ finds, a foundation by which the reader is «oriented» in a novel where introspection, retrospection, and internal monologue are so prevalent.

\section{THE FILM ADAPTATION FAREWELL UNTIL THE NEXT WAR}

The film canon of Živojin Pavlovič (1933-1998), Serbian director, screenwriter, critic, writer, and one of the most important representatives of the so-called "black wave" in Yugoslav film, comprises 13 feature-length movies, of which 9 screenplays are based on literary works. Pavlović also looked to Slovenian literature for his movies' inspiration - he filmed Crveno klasje (Red Wheat) in 1970, an adaptation of Ivan Potrč's novel Na kmetih (The Land and the Flesh), while in 1980 he filmed Farewell until the Next War. In addition Pavlović and screenwriter Neboljša Pajkić wrote a screenplay for a movie with the working title Kazenski bataljon (March Battalion) ${ }^{25}$, based on the novel Resničnost (Reality) by Lojze Kovačič, although the movie was never filmed ${ }^{26}$.

Farewell until the Next War $^{27}$ premiered at the 1980 Pula Film Festival, and a little later in Slovenia, while it was screened in Cannes in 1982, receiving positive international criticism ${ }^{28}$. Reactions in then Yugoslavia were mixed: positive criticism focused on the extraordinary camera work and recognized his authenticity, convincingness, excellently portrayed war scenes, antiheroic plasticism, aesthetic violence, and shocking confession ${ }^{29}$, while another wave of criticism came due to the perceived devalued portrayal of the Partisan movement. Pavlović was accused of having completely ignored the question of the war of criminal aggression and conquering, as well as of the fair defensive and liberation war, as if there were no differences at all ${ }^{30}$. As a result the film was ignored by the jury at the Pula festival, and after a few showings

${ }^{24}$ A. Zupan Sosič, Pimlico in Neznosna lahkost bivanja kot maturitetna romana, „Jezik in slovstvo”, 2006, vol. 51, no 6, p. 28.

25 The entire screenplay was published in the film journal Kino! Cf., N. Pajkić and Ž. Pavlović, Kazenski bataljon, „Kino!”, 2012, no 6, p. 230-356.

${ }^{26}$ Prekletstvo iskanja resnice. Filmska ustvarjalnost in teorija Živojina Pavlovića, ed. A. Šprah, Ljubljana 2012, p. 97-106; 261-275.

27 Screenplay: Živojin Pavlović, director of photography: Tomislav Pinter, music: Bojan Adamič, scenography: Mirko Lipužič, costumes: Irena Felicijan, makeup: Anka Vilhar, audio: Matjaž Janežič, editing: Olga Skrigin, actors (principal roles): Metod Pevec (Berk), Boris Juh (Anton), Hans Christian Blech (Bitter), Milan Puzić (the old Berk), Ruth Gassmann (Mrs. Bitter), production: Viba film, Vesna film, director: Vera Mihić-Jolić. Filmografija slovenskih celovečernih filmov 1931-2010, ed. S. Rugelj, Ljubljana 2011, p. 168. Cf. Ž. Pavlović, Nasvidenje v naslednji vojni. Ljubljana 1980, DVD.

${ }_{28}$ S. Šimenc, Slovensko slovstvo v filmu, Ljubljana 1983, p. 199.

${ }^{29}$ Ibidem, p. 198.

${ }^{30}$ Z. Vrdlovec, Zgodovina filma na Slovenskem 1896-2011, Ljubljana 2013, p. 476. 
in Slovenia it was removed from theaters ${ }^{31}$. Modern film criticism, however, places the work among the greatest accomplishments in Slovenian film ${ }^{32}$.

Pavlović, known as a director with a realistic and naturalistic approach to portraying stories ${ }^{33}$, preserved the dual spatial and temporal structure of Minuet for Guitar in the novel's film adaptation. The technique of the long shot (a long sequence without any editing breaks), which is characteristic of Pavlović's cinematic poetics and is one of the modes of realistic expression ${ }^{34}$, is interwoven with naturalistic scenes (animals being slaughtered), scenes with close-ups and details, which acquire their symbolic value (depicting a mythological figure on a musical saw, the grenade lighter); at the same time it maintains its own (cinematic) modernist narrative discourse.

\section{MODERNIST NARRATIVE TECHNIQUES IN FAREWELL UNTIL THE NEXT WAR}

Cinematic modernism is characterized by the fragmentation of time and space, which are joined in the editing process into a so-called discontinuous continuum; the dramatic events are not linear and self-contained, but are portrayed in fragments, and the narrative is destabilized. The narrative is a web of symbolic and real layers, the imaginary and the factual, and the cinematic means of expression portray the internal status of the film's characters, as well as their subjective perception, through which subjective time is established ${ }^{35}$.

Farewell until the Next War preserves the literary original's fragmented spacetime and events. The fragments of the Partisan and Spanish spatial and temporal lev$\mathrm{el}^{36}$ are linked in the cinematic version with fluid transitions (parallel editing), as some fragments or their variations are repeated in the film's narrative (Anton's death, the German soldier who spies Berk but does not give up his position). The transitions from the Spanish chronotope to the Partisan memory (retrospective or flashback) ${ }^{37}$ are encouraged by Bergant's thoughts, conversations with Bitter, an observation of

31 S. Šimenc, Slovensko slovstvo v filmu, Ljubljana 1983, p. 199.

32 S. Popek, Naturalistična „podoba-nagon”: Živojin Pavlović v Sloveniji, „Ekran; revija za film in televizijo", 2005, no 1-2, p. 20.

33 Prekletstvo iskanja resnice. Filmska ustvarjalnost in teorija Živojina Pavlovića, ed. A. Šprah, Ljubljana 2012, p. 7-21.

${ }^{34}$ A. Šprah, Živojin Pavlović in partizanski film: razgradnja vizije pridobitev vojne in revolucije, „Kino!”, 2012, no 17-18, p. 230-272.

35 B. Zorman, Sence besede. Filmske priredbe slovenske literature (1948-1979), Koper 2009, p. $107-$ $113 ; 135-142$.

36 The opening scenes and the final ones feature as the space where events take place, Ljubljana in the time of Italian occupation as well as after liberation. Since these parts of the film are not essential for the issue of portraying modernist narrative techniques, this article does not treat this chronotope in more detail.

37 This is an editing technique by which a sequence of events in the present are interrupted by a scene or sequence of scenes representing past events (L. Giannetti, Razumeti film, Ljubljana 2008, p. 575). 
current events (e.g. Easter Celebrations in Spain, bullfighting), or some material object. In terms of audiovisuals this is heralded by, e.g., Bergant's looking off into the distance, a gradual blurring of the picture, a camera close-up (the lighter shaped like a grenade), Bergant's statements (I think about that time often), or connected motifs (Bergant and Bitter talk about bullfighting, and then the scene cuts and the next scene is during boxing training in occupied Ljubljana). Identically designed scenes in some places also form the link between the two chronotopes. Berk is spied by a young German soldier during the war, but is not betrayed; instead the soldier moves onward, likely saving Berk's life. The German soldier is filmed in a close-up (face shot and medium close-up) $)^{38}$, and as he turns to look, the left side of his face is visible. The same design features in the scene, 30 years later, when in Spain Bergant first meets Bitter. While watching a bullfight Bergant sits a few seats behind Bitter, who all of a sudden turns his glance, and then the same left side of his face is visible. This uncanny similarity evokes Bergant's memory, and the subsequent scene/sequence shows Berk in Ljubljana, before joining the Partisans. The transition to consciousness therefore often occurs on an associative basis (a thematic montage), while the reminiscences are more blurred than the Spanish contemporary events, and the Partisan scenes ${ }^{39}$ are shot in lower-fidelity color than the Spanish ones.

In addition to the exchange between temporal and spatial levels, the film adaptation makes use of other means of expression in the form of fragmented sections to show the interweaving of the literature and the film, the extra-cinematic (historical) and cinematic realities, which I have labeled an "audiovisual" quotation. An audiovisual quotation is a recording or printout of a text from a work of literature, or a copy of a photograph that, as an independent scene, is shown on screen and that can be accompanied by music or other audio background. In the novel in question individual chapters contain a preface with the author's various musings, and the film similarly begins and ends with a quote. The opening scene shows a photograph, in which a group of people are listening to a guitarist in front of a chapel. The picture is supplemented with a printed quote from Slovenian writer Ivan Cankar's (1876-1918) Kakadu (Cockatoo), which is also featured in the novel: All about us are thousands of lives unknown to us, whose secrets are unfathomable. A child feels some awareness of them, hence his timid susceptibility. Every sound you hear is a sound from beyond ${ }^{40}$. A sequence is placed at the end of the film that is a recording of or reference to the content and composition of the photograph from the beginning: Berk watches people gathered

${ }^{38} \mathrm{I}$ list both possibilities, as the same content is repeated in two scenes. As Bergant remembers, while watching the bullfight in Spain, that moment when he met the German soldier, we see a scene with that soldier, where just his left profile is visible (face shot). Later, in a longer sequence, the events before and after meeting the German soldier are shown, and the viewer sees the soldier in a close-up (medium close-up).

39 The term "sequence" is used here as a long scene with several levels of events and camera movement, while "scene" is a smaller unit in an edited movie, marked by uninterrupted portrayal, filmed either with a static or moving camera (Giannetti, Razumeti film, Ljubljana 2008, p. 576).

${ }^{40}$ V. Zupan, Minuet for Guitar, Champaign/Dublin/London 2011, p. 73. 
before the burned village chapel, while the guitarist sings a song in Spanish. The scene imposes the Spanish (music) upon the Slovenian (chapel, Partisans) space, and at the same time the introductory scene/photograph interweaves the real and the imaginary, such that it juxtaposes the objective (documentary photography) with the subjective (Berk's visualization) memory of the war.

The director used the described means of expression to interlink the spatial and temporal levels of the narrative and establish a complex chronotope, which includes an additional, subjective dimension - namely the protagonist's consciousness:

\begin{abstract}
When I decided to mess with the time levels, I decided to go all the way. [Namely] to add to this objective temporal parallelism that third level of extreme subjectivization in temporal experience. Besides, we all have all stored experiences of conflated intensity, which in their temporality break through the prism of our subjectivization in total discord with the true temporal ordering of these events in material life $e^{41}$.
\end{abstract}

The entrance to Bergant's consciousness, where there is a jumble of Partisan memories and later experiences, as well as the search for explanations especially for past events, is introduced by scenes from the Spanish temporal level. Before the cinematic enactment of the anti-Partisan skirmish there is a scene that shows the Bergant and Bitter in the distance on the terrace of a Spanish hotel, and the skirmish follows immediately after that. Audiovisually the memory is staged in a blurred scene; in parts two scenes even overlap, or one transitions to the next, with no dialog, and the Tango motif from Francisco Tárrega, heard off-screen ${ }^{42}$. The sequence lasts for several minutes, and the scene of the action and the intensity of the lighting (day, dusk, night), as well as the music and the image of the Partisans, stay in constant movement. The several days of intense effort cause Berk to begin hallucinating - a subjective camera (a camera that shows in POV that which the observing person, therefore Berk, is seeing) shows a house at dusk, in which the silhouettes of couples dancing can be seen, and Berk stares inside as he passes by. It is clear that this is a fantasy from the script, where the authors planned the portrayal of this extreme state of consciousness: Everything is dancing before Berk's eyes. The music gets louder. Like drunkards they approach the huts and wooden houses. It seems to Berk that the windows are very lit up, and that many shadows - couples wearing Partisan titovka caps - dance, dance to the rhythm of the music ${ }^{43}$.

Bergant's obsession with memories continuously returns to the fore, and the movie does not just stage them as a part of scenes from the past (memory sequences),

${ }^{41}$ Quote for: A. Šprah, Živojin Pavlović in partizanski film: razgradnja vizije pridobitev vojne in revolucije, "Kino!", 2012, no 17-18, p. 269.

42 An off-screen voice or music is one that does not originate from within the film, but is considered the acoustical background that the audience hears, but not the film's characters. Critics refer to this as non-diegetic sounds, while the diegetic are the ones that are heard by the characters as well (Giannetti, Razumeti film, Ljubljana 2008: p. 233). The musical motif of the Tango occurs as a non-diegetic part of the cinematic sequence.

43 Ž. Pavlović, Nasvidenje v naslednji vojni, script, Ljubljana 1979, no 1327, p. 141. 
but they also become a part of Bergant's everyday ritual on holiday, interwoven into the Spanish scenes. When he walks along the coast in Spain, the camera shifts focus from the protagonist to mysterious figures underneath the pier. In them we recognize Berk's Partisan colleagues, staring unmoving either into the distance or into the camera, while dead bodies lie between them, civilians sit still, and bits of barbed wire lie heaped about. The scene is accompanied by the already known musical motif of Tango. Šprah ${ }^{44}$ calls this scene the "dance macabre", as those under the pier are ones who died in the war, but they still exist in Berk's memory, accompanying him as some sort of paranoia. In addition to Bergant's memories of his fellow soldiers he is also obsessed with thoughts about the death of his Partisan friend Anton, a former fighter in the Spanish civil war. The absurd death of the experienced soldier, who during the celebrations of the end of the war was accidentally shot by friendly fire, completely destroys Berk. The sequence with Anton's death is repeated twice, but without voices, natural sounds, or the sounds of weapons, just accompanied by the Tango, in slow motion, and with a blurred camera.

These cognitive meditations in their direct form also appear in the dialogs between Berk and Anton, as well as (especially in the final sequences) between Bergant and Bitter. The audience, especially those who are familiar with the literary original, or at least with the social and political background surrounding the historical period in question, can directly recognize these cognitive meditations (e.g. on the role and insignificance of the individual in the context of historical events, on the individual as a tool for the political elite to gain its goals, on the cruelty of humans in their relationships with animals and fellow man, on his disappointment with society and the system) through the interpretation of individual film sequences (e.g. the camera zooms in on Berk's disappointed face after his conversation with Anton about the government and stays there a few seconds in close-up; the head of the dead freedom fighter next to the head of a dead horse), which remain open enough so as to give the audience a chance for deeper reflection.

\section{CONCLUSION}

The fragmentary nature of the narration in the film Farewell until the Next War interweaves two chronotopes - the Spanish and the Partisan - the latter of which is supplemented by the Ljubljana chronotope, the whole time accompanied by the chronotope of consciousness. Individual fragments of the various event "space-times" are arranged and logically linked in the film version into a comprehensive narrative through the technique of traditional editing (D. W. Griffith; parallel and thematic editing), which connects individual parts of the narrative by directing attention to detail, on the basis of thematic or cognitive associations, and thus establishes a space-time contin-

${ }^{44}$ A. Šprah, Živojin Pavlović in partizanski film: razgradnja vizije pridobitev vojne in revolucije, “Kino!", 2012, no 17-18, p. 244. 
uum. Just as in the novel, stream of consciousness is one of the film's main narrative techniques, as the majority of the events are comprised of the experience of and reflection upon Bergant's past. The sequences from Spain serve as introductory scenes for transitions into Bergant's consciousness or memory. This transition can take the form of a simple cut, or a thematic link, and sometimes the transition is signaled visually as well, with a close-up of Bergant's eyes, with gradual fading, and with the less vibrant color of the Partisan chronotope. The two events most deeply rooted in Bergant's consciousness (the anti-Partisan skirmish and Anton's death) are shown least realistically, both with similar techniques: blurring, overlapping images, slow motion, absence of natural sounds, non-diegetic music (the off-screen Tango), and variated repetition of individual scenes. Nonetheless the film's narrative remains connected and does not break down into individual incoherent parts, which does in fact occur in the novel at the contextual and linguistic level. At the end of the film Bergant's thoughts about the past become so intense that there is no longer any need for the cut screen to transition to the Partisan chronotope, as memory - of the dead Partisan colleagues under the pier - also becomes a part of the Spanish theater of space and time. The essayistic parts of the narrative, which in the novel serve to accentuate Bergant's thoughts about the point of life, relativity, humanity's insignificance, cruelty, etc. (desubjectivization of the subject), are shown verbally in the film, as conversations between Berk and Anton, and between Bergant and Bitter. They are also heralded visually, e.g. with close-ups, when the camera zooms in and remains fixed on a thinking face, or on a scene that attracts attention, but these are nonetheless expressed to a lesser extent than in the novel.

\section{ACKNOWLEDGEMENTS}

This paper is based in part on the analysis conducted for research on the doctoral dissertation The Polish and Slovenian Literary Canon from the Period of Modernism as Film Adaptation ${ }^{45}$, under the mentorship of prof. Dr. Nikolaj Jež and co-mentor prof. Dr. Igor Koršič. There is an article on this, published in Slovene in "Philological Studies" 46 . With the permission of the journal's editors it was translated into English, in a slightly different form.

\section{REFERENCES}

Barbarič Nada, Uvodna razlaga, in: Menuet za kitaro, Vitomil Zupan, Ljubljana 1999, p. 13-37.

Berger Aleš, Na poti skozi čas in za seboj, in: Menuet za kitaro, Vitomil Zupan, Ljubljana 1984, p. 543563.

${ }^{45}$ L. Rezoničnik, Poljski in slovenski literarni kanon obdobja modernizma v filmski adaptaciji, Ljubljana 2014, p. 81-95.

${ }^{46}$ L. Rezoničnik, Modernistični pripovedni postopki v filmski adaptaciji romana Menuet za kitaro, „Filološke pripombe”, vol. 15, no 1, p. 72-85. 
Dolgan Marjan, Vitomil Zupan, Menuet za kitaro, „Sodobnost”, 1976, vol. 24, no 2, p. 172-176.

Eysteinsson Astradur, The concept of modernism, Ithaca/London 1992.

Giannetti Louis, Razumeti film, Ljubljana 2008.

Harlamov Aljoša, Slovenski modernistični roman. Doctoral thesis, Ljubljana 2016, p. 6-94; 108-121.

Kermauner Taras, Vztrajati, vsemu navkljub (Ob Zupanovem Menuetu), in: Menuet za kitaro, Vitomil Zupan. Murska Sobota 1980, p. 477-487.

Kos Janko, Konec modernizma, „Sodobnost”, 1988, vol. 36, no 3-7, p. 240-251; 386-393; 513-520: 655-662. Dlib. http://www.dlib.si/details/URN:NBN:SI:DOC-1KDYMBNY/?euapi=1\&query=\%2 7keywords\%3dkonec + modernizma\%27\&pageSize $=25$ [Access: 03.09. 2017].

Kowalska Urszula, Janusova obraza zgodovine, in: Menuet za kitaro, Vitomil Zupan. Ljubljana 1984, p. 564-581.

Kuśmierczyk Seweryn, Wyprawa bohatera w polskim filmie fabularnym. Warsaw 2014, p. 11-34.

Pavlović Živojin, Nasvidenje v naslednji vojni, Ljubljana 1979, script no. 1327.

Pavlović Živojin, Nasvidenje v naslednji vojni, DVD, Ljubljana 1980.

Popek Simon, Naturalistična ,podoba-nagon”: Živojin Pavlović v Sloveniji, „Ekran; revija za film in televizijo", 2005, vol. 42, no 1-2, p. 20.

Rezoničnik Lidija, Poljski in slovenski literarni kanon obdobja modernizma v filmski adaptacji, Doctoral thesis, Ljubljana 2014, p. 81-95.

Rezoničnik Lidija, Modernistični pripovedni postopki v filmski adaptaciji romana Menuet za kitaro, „Filološke pripombe”, 2017, vol. 15, no 1, p.72-85.

Rudolf Matevž, Ko beseda podobo najde. Slovenska literatura in film v teoriji in praksi (1984-2012), Ljubljana 2013, p. 73-143.

Rugelj Samo (ed.), Filmografija slovenskih celovečernih filmov 1931-2010, Ljubljana 2011, p. 168-169.

Šimenc Stanko, Slovensko slovstvo v filmu, Ljubljana 1983, p. 194-199.

Škulj Jola, Modernizem in njegove poteze v lirski, narativni in dramski formi. „Primerjalna književnost”, 1998, vol. 21, no 2, p. 45-74.

Šprah Andrej (ed.), Prekletstvo iskanja resnice. Filmska ustvarjalnost in teorija Živojina Pavlovića, Ljubljana 2012.

Šprah Andrej, Živojin Pavlović in partizanski film: razgradnja vizije pridobitev vojne in revolucije, „Kino!”, 2012, vol. 6, no 17-18, p. 230-272.

Vrdlovec Zdenko, Zgodovina filma na Slovenskem 1896-2011, Ljubljana 2013, p. 469-476.

Zorman Barbara, Sence besede. Filmske priredbe slovenske literature (1948-1979), Koper 2009, p. 13$51 ; 103-160$.

Zupan Vitomil, Menuet za kitaro, Ljubljana 1984.

Zupan Vitomil, Minuet for Guitar, Champaign/Dublin/London 2011.

Zupan Sosič Alojzija, Pimlico in Neznosna lahkost bivanja kot maturitetna romana, „Jezik in slovstvo”, 2006, vol. 51, no 6, p. 25-45.

Zupan Sosič Alojzija, Govor v sodobnem slovenskem romanu, „Slavistična revija”, 2015, vol. 63, no 2, p. $183-195$. 